\title{
Can Complete Blood Count Inflammation Markers Be Used to Predict Graft Success After Tympanoplasty?
}

\author{
Timpanoplasti Sonrası Greft Başarısını Ön Görmede Tam Kan Sayımı Enflamasyon \\ Belirteçleri Kullanılabilir mi?
}

(1) Zehra Çınar, (1) Özgür Yiğit, (1) Ahmet Volkan Sünter

İstanbul Training and Research Hospital, Clinic of Otorhinolaryngology and Head and Neck Surgery, İstanbul, Turkey

\begin{abstract}
Introduction: This study aimed to investigate the effect of preoperative neutrophil lymphocyte ratio (NLR), platelet lymphocyte ratio (PLR), eosinophil lymphocyte ratio (ELR), basophil lymphocyte ratio (BLR) and lymphocyte monocyte ratio (LMR) on graft success after tympanoplasty.

Methods: Forty-five patients who underwent tympanoplasty with temporal fascia graft between January 2017 and December 2019 were included in this study. The patients were divided into two groups: intact (13 men, 12 women) and perforated ( 13 women, 7 men) according to their postoperative graft results. Demographic data and routine complete blood count parameters, such as NLR, PLR, ELR, BLR and LMR, as well as intraoperative middle ear characteristics were compared for both the groups.

Results: The following parameters did not differ significantly differ $(p>0.05)$ in both groups: age; gender; side; middle ear condition; platelet, neutrophil, lymphocyte, eosinophil, monocyte and basophil counts; NLR; PLR; ELR; BLR and LMR.

Conclusion: From the results, it can be concluded that NLR, PLR, ELR, BLR and LMR, which are markers of inflammation in the preoperative period, cannot be used to predict graft success in patients who will undergo tympanoplasty for chronic otitis media.
\end{abstract}

Keywords: Chronic otitis media, inflammation, graft success, perforation

\section{öz}

Amaç: Bu çalışmanın amacı preoperatif nötrofil lenfosit oranı (NLO), platelet lenfosit oranı (PLO), eozinofil lenfosit oranı (ELO), bazofil lenfosit oranı (BLO) ve lenfosit monosit oranı (LMO)'nın temporal fasya grefti kullanılan timpanoplasti öncesi greft başarısını ön görmede kullanılabilirliğini ortaya koymaktır.

Yöntemler: Ocak 2017-Aralık 2019 tarihleri arasında kliniğimizde kronik otitis media nedeniyle temporal fasya grefti ile timpanoplasti yapılan hastalar grefti başarılı olan intakt grup (13 erkek,12 kadın) ve grefti bașarız olan perfore grup (13 kadın, 7 erkek) olmak üzere iki gruba ayrıldı. Bu iki grup yaş, taraf ve cinsiyet ile tam kan sayımında hücre sayıları ve NLO, PLO, ELO, BLO ve LMO ve orta kulağın durumu açısından karşılaştıııldı.

Bulgular: Intakt ve perfore gruplarda yaş, cinsiyet dağılımı, taraf ve orta kulağın durumu ile platelet, nötrofil, lenfosit, eozinofil, monosit, bazofil sayıları ve NLO, PLO, ELO, BLO ve LMO anlamlı $(p>0,05)$ farklılık göstermemiștir.

Sonuç: Bu çalışmanın bulguları ıșığında kronik otitis medya nedeniyle timpanoplasti uygulanacak hastalarda preoperatif dönem enflamasyon belirteçleri olan NLO, PLO, ELO, BLO ve LMO'nun greft başarısını ön görmede kullanılamayacğı sonucuna varılmıştır.

Anahtar Kelimeler: Kronik otitis media, enflamasyon, greft bașarısı, perforasyon

\section{Introduction}

Otitis media is a chronic inflammation and infection of the middle ear and mastoid cavity characterized by hearing loss and ear discharge (1). Type 1 tympanoplasty is tympanic membrane perforation repair, first performed by Berthold (1878) and later popularized by wullstein and Zollner (1950) (2). Many methods and graft materials have been used in tympanic membrane perforation repair until today. The most commonly used graft material is the temporal fascia (3).
Neutrophil lymphocyte ratio (NLR), platelet lymphocyte ratio (PLR), eosinophil lymphocyte ratio (ELR), basophil lymphocyte ratio (BLR) and lymphocyte monocyte ratio (LMR) are increasingly used in many medical disciplines. In chronic inflammatory pathologies, the number of neutrophils and platelets increases, while the number of lymphocytes decreases (4). The prognostic value of NLR and PLR as indicators of systemic inflammatory response in many types of cancer has found a wide range of research areas (5). On the other hand, it has been suggested 
that the character of otitis media with effusion can be determined by calculating NLR and PLR in the preoperative period and that unnecessary surgical procedure can be avoided (6). Eosinophils and basophils are leucocytes with proinflammatory effect and multifunctional properties that are involved in the pathogenesis of parasitic and allergic diseases (4). The relationship of monocyte/lymphocyte ratio with prognosis in many types of cancer has also been investigated $(7,8)$.

It is very important to be able to predict post-operative graft success in the preoperative period. Realistic expectations and the possibility of revision surgery can only be talked to patients in this way. In the literature, the success rate of fascia graft and tympanic membrane perforation repair ranges between $75-90 \%$. Temporal fascia graft is the most commonly used graft material in tympanoplasty operations, but since the success rate is variable, otologists have tried to use different grafts to improve graft success $(3,9,10)$.

The aim of this study is to determine the availability of NLR, PLR, ELR, $B L R$ and LMR in preoperative period to predict graft success prior to tympanoplasty using temporal fascia graft.

\section{Methods}

Approval was obtained from İstanbul Training and Research Hospital Ethics Committee for this study on 07.02.2020 (decision no: 2177).

\section{Study Design}

This study is a retrospective comparative study based on the medical records of patients who underwent type 1 tympanoplasty surgery at the İstanbul Training and Research Hospital, Clinic of Otorhinolaryngology and Head and Neck Surgery (ENT-HNS) between 2017 and 2019.

\section{Study Population}

Between January 2017 and December 2019, the medical records of 769 patients who underwent tympanoplasty surgery at the İstanbul Training and Research Hospital, Clinic of ENT-HNS were reached. Patients who did not meet the criteria for inclusion in the study were excluded from

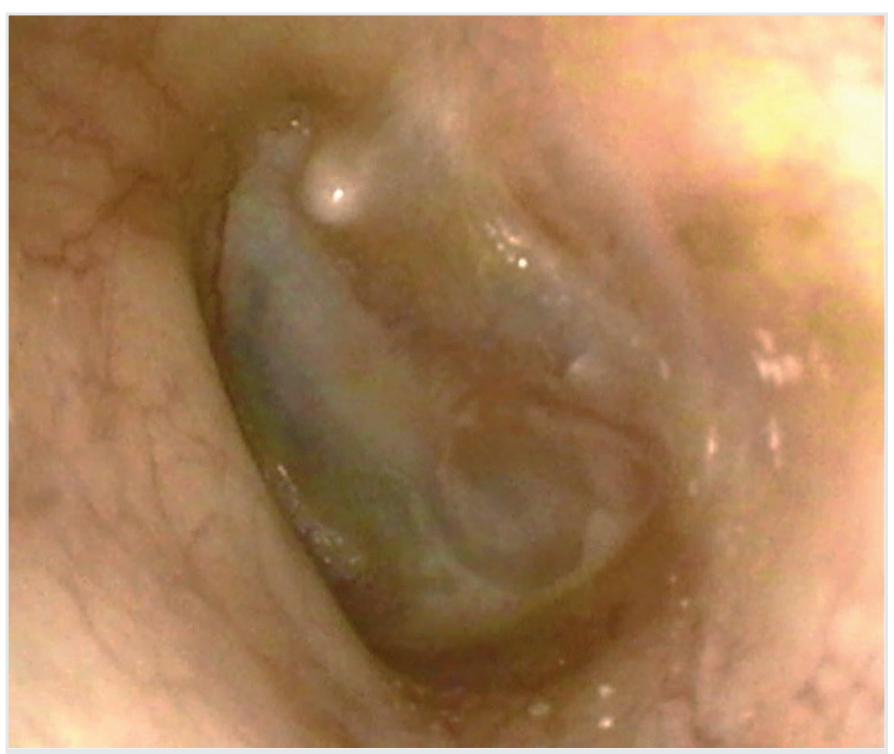

Figure 1. Graft intact after tympanoplasty the study. The patients who underwent tympanoplasty using temporal fascia graft were divided into two groups according to whether the graft was successful in the second month of post-operative: graft successful (Figure 1) group: 27 patients, graft failed (Figure 2) group: 20 patients. These two groups were compared with each other in terms of age, side, gender and middle ear condition and in terms of NLR, PLR, ELR, BLR and LMR in preoprative blood counts.

\section{Criteria for Inclusion in the Study}

Patients between the ages of 15-65 who had a persistent tympanic membrane perforation that had been dry for at least three months prior to surgery and type 1 tympanoplasty using an intraoperative fascia graft were included in the study.

\section{Exclusion Criteria}

Patients with cholesteatoma, prior autological surgery with concomitant mastoidectomy, contralateral tympanic membrane perforation, nonintact bony chain, smokers, additional disease that may disrupt middle ear pneumatization (nasal septal deviation, cleft palate,...), additional systemic disease that may trigger systemic inflammation (hypertension, cardiac diseases, oncological malignancies...), patients who were $<15$-years-old and >65-years-old who had type 1 tympanoplasty using a graft material other than fascia graft were excluded.

\section{Surgery}

Oral and written informed consent was obtained from all patients prior to surgery. Operation technique was standard in both groups. The temporal muscle fascia was taken using postauricular incision under general anesthesia, dried and placed using the over and underlay technique (Figure 3).

\section{Determining Cell Rates}

Preopeartive complete blood count results were used to calculate NLR, PLR, ELR, LMR and BLR. These two groups were compared statistically in terms of age, gender, location of perforation, size of perforation,

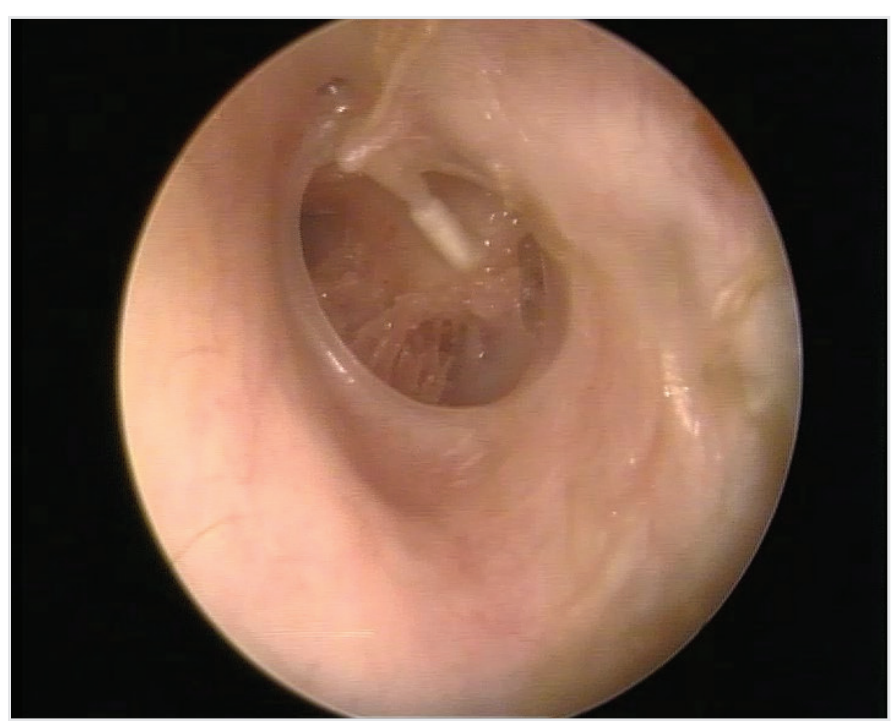

Figure 2. Graft perforated after tympanoplasty 
condition of middle ear mucosa and preoperative NLR, PLR, ELR, LMR and $B L R$ values.

\section{Statistical Analysis}

Mean, standard deviation, median lowest, highest, frequency and ratio values were used in the descriptive statistics of the data. The distribution of variables was measured by Kolmogorov-Simirnov test. The MannWhitney $U$ test and independent sample test were used in the analysis of quantitative independent data. The chi-square test was used for

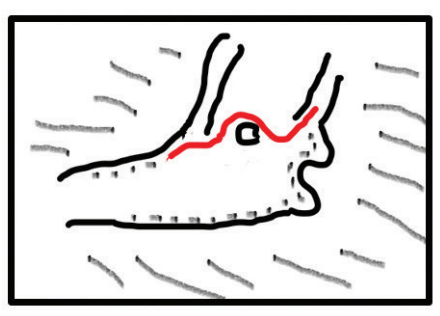

OVER-UNDERLAY

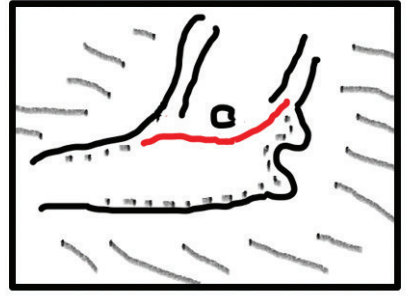

UNDERLAY
Figure 3. Overlay technic and over underlay technic the analysis of qualitative independent data; the fischer excat test was used when the chi-square test conditions were not met. The SPSS 26.0 program was used in the analyses.

\section{Results}

The ages of the patients in the two groups with fascia graft intact and perforated after tympanoplasty, were not significantly different $(p>0.05)$. Gender distribution and smoking rate of patients in intact and perforated graft groups did not differ significantly $(p>0.05)$ (Table 1).

Platelet count, neutrophil count, lymphocyte count did not differ significantly $(p>0.05)$ in groups with graft intact and perforated. The eosinophil count, monocyte count, and basophil count did not differ significantly $(p>0.05)$ in groups with graft intact and perforated (Table 1$)$.

PLR and NLR were not significantly different in intact and perforated graft groups $(p>0.05)$. The ELR and BLR of patients in intact and perforated graft groups did not differ significantly $(p>0.05)$ (Table 1$)$. LMR was not significantly different in intact and perforated graft groups $(p>0.05)$ (Table 1).

The right and left ear ratio of patients with intact and perforated grafts did not differ significantly $(p>0.05)$. The middle ear condition of patients

Table 1. Comparison of groups in terms of clinical, operation side, middle ear mucosa and cell counts and ratios in whole blood count test

\begin{tabular}{|c|c|c|c|c|c|c|c|}
\hline & & Intact & & Perforated & & & \\
\hline & & Ave $\pm S D / n-\%$ & Median & Ave \pm SD / n- $\%$ & Median & p & \\
\hline Age & & $34.3 \pm 12.4$ & 36.0 & $32.1 \pm 12.3$ & 30.5 & 0.559 & $\mathrm{t}$ \\
\hline Condo & Female & $12 / 48.0 \%$ & & $13 / 65.0 \%$ & & ( & $x^{2}$ \\
\hline Gerruet & Male & $13 / 52.0 \%$ & & $7 / 35.0 \%$ & & 0.234 & \\
\hline Platelet count & & $269.3 \pm 48.5$ & 276.0 & $267.1 \pm 104.1$ & 266.0 & 0.404 & m \\
\hline Neutrophile count & & $4.1 \pm 0.9$ & 4.0 & $4.1 \pm 1.3$ & 4.0 & 0.958 & $t$ \\
\hline Lymphocyte count & & $2.4 \pm 0.6$ & 2.2 & $2.3 \pm 0.6$ & 2.3 & 0.803 & t \\
\hline Platelet lymphocyte & & $121.0 \pm 37.7$ & 109.9 & $116.2 \pm 27.6$ & 118.6 & 0.636 & t \\
\hline Neutrophile lympho & ratio & $1.8 \pm 0.5$ & 1.8 & $1.9 \pm 0.9$ & 1.7 & 0.641 & t \\
\hline Eosinophil lymphoc & & $0.1 \pm 0.1$ & 0.0 & $0.1 \pm 0.1$ & 0.1 & 0.157 & $\mathrm{~m}$ \\
\hline Lymphocyte monoc & & $4.2 \pm 1.4$ & 3.8 & $4.2 \pm 1.3$ & 4.4 & 0.840 & $\mathrm{t}$ \\
\hline Basophobia lympho & catio & $0.0 \pm 0.0$ & 0.0 & $0.0 \pm 0.0$ & 0.0 & 0.646 & t \\
\hline Ear & Right & $15 / 60.0 \%$ & & $8 / 40.0 \%$ & & 0107 & $x^{2}$ \\
\hline Lar & Left & $10 / 40.0 \%$ & & $12 / 60.0 \%$ & & 0.182 & \\
\hline & Normal & $23 / 92.0 \%$ & & $18 / 90.0 \%$ & & & \\
\hline
\end{tabular}

${ }^{\mathrm{m}}$ Mann-Whitney U test, ${ }^{{ }^{x} 2}$ chi-square test, 'Unpaired t test, Ave: average, SD: standard deviation 
with intact and perforated grafts did not differ significantly ( $p>0.05)$. (Table 1).

\section{Discussion}

Tympanoplasty is a surgical procedure to close tympanic membrane perforation and improve hearing. Many graft materials have been used for tympanic membrane reconstruction so far $(9,11)$. Temporal muscle fascia shows variable success rates but are still the most commonly used graft material (11).

The success of tympanoplasty can vary depending on the patient, the size of the middle ear pathology, the graft material and the surgical technique (9). In patients with eustachian tube dysfunction, retraction pocket, adhesive middle ear disease and subtotal or total perforation, more graft failure was revealed by temporal fascia graft (11). The success rate of the temporal fascia graft after tympanoplasty was found to be lower in young (<16-years-old) patients, patients with bilateral middle ear disease and accompanying anatomical disorder that may affect the ventilation of the middle ear, such as adenoid vegetation, cleft palate, and apparent septal deviation $(3,9,10)$. It was stated that these patients were not suitable candidates for tympanoplasty with temporal fascia graft. Similarly, it was revealed that graft success rate with fascia graft was much lower in revision surgeries $(9,10)$. Smoking has been reported as the solely factor associated with high graft failure in cartilage tympanoplasty (12).

Even if negative prognostic factors are eradicated, graft success after tympanoplasty with temporal muscle fascia can range between $80-97 \%$ $(3,13)$. No useful marker has been found for predicting postopeartive tympanic membrane perforation recurrence in preoperative period except for the prognostic factors mentioned today. PLR and NLR have been used to predict prognosis and recurrence in many diseases, such as malignancies and infectious/noninfectious pathologies (14). NLR can be easily calculated from routine complete blood cell count (BCC) as a good indicator of inflammatory condition. NLR has been investigated in many diseases in otolaryngology and it has been revealed that more nasal polyp recurrence develops in patients with increased NLR compared to patients with low NLR (4). In a study by He et al. (15), in patients with nasopharyngeal cancer, increased NLR before treatment was associated with poor survival rates. In another study, higher NLR was encountared in stage IV larynx cancer compared to clinical stage III (16). Increased idiopathic sudden sensorineural hearing loss was associated with poor prognosis of increased NLR (17). In this study, no statistically significant difference was found between the intact and perforated groups in terms of NLR. PLR is another marker that can be easily calculated from a complete $\mathrm{BCC}$ to assess inflammatory conditions. In advanced-stage malignancies, pre-treatment high PLR was found to be associated with low survival rates (18). It has been demonstrated that increased PLR has a negative effect on prognosis in cardiovascular diseases (19). PLR is used in otolaryngology, especially in head and neck cancers. It was emphasized that increased PLR in head and neck cancers is compatible with low survival rates (20). It was also evaluated in sinonasal polyp recurrence and increased PLR was found to be associated with recurrence (21). In this study, no statistically significant difference was found between two groups with and without graft succes after tympanoplasty in terms of PLR.

ELR and BLR are other rates that present the inflammatory state and they can be easily calculated. Eosinophils and basophils are closely related to allergic conditions and parasitic infections $(22,23)$. In the study in which Kökoğlu and Șahin (4) measured patient satisfaction after septoplasty, patient's dissatisfaction after septoplasty was found to be proportional with high ELR and BLR and high eosinophil and basophil counts. In the clinical study conducted by Kara et al. (24), a statistically significant correlation was found between nasal polyposis severity and ELR in patients with nasal polyposis. Higher ELR was found as a new inflammatory marker in smokers compared to non-smokers (25). It has been demonstrated that NLR and ELR can be used as a marker of occult inflammation and disease activity in patients diagnosed with achalasia (26). In systemic autoimmune rheumatic diseases, ELR and BLR may vary depending on the disease. It has been shown that in many systemic autoimmune rheumatic diseases, BLR is decreased, while ELR is decreased in systemic lupus erythematosus and increased in other systemic autoimmune rheumatic diseases (27). In this study, no statistically significant difference was found between the intact group whose graft was successful and the perforated group whose graft was unsuccessful in terms of ELR and BLR.

In recent years, LMR has been recognized as an important indicator of endothelial dysfunction and inflammation that have with prognostic and predictive value in different populations. Although the relationship between low LMR and increased mortality has not been fully clarified, high monocyte count or low lymphocyte count have been associated with poor prognosis in various pathologies $(28,29)$.

A significant decrease in overall and disease-free survival was found in patients diagnosed with T-cell lymphoblastic leukemia and with LMR value $\geq 2.8$ when evaluated together with high NLR and PLR (29). A significant correlation was found between high LMR value before treatment and overall and disease-free survival in patients with head and neck cancer (30). In this study, no statistically significant difference was found between two groups with and without graft succes after tympanoplasty in terms of LMR.

The aim of this study was to evaluate the availability of preoperative NLR, PLR, ELR, BLR and LMR values to predict graft success in patients whose operation is planned due to chronic otitis media. The results of this study showed that there was no statistically significant correlation between graft success and NLR, PLR, ELR, BLR and LMR.

\section{Conclusion}

As a result, the success rate of graft after tympanoplasty may vary depending on multifactorial causes. In the light of the findings of this study, it has been concluded that preoperative NLR, PLR, ELR, BLR and LMR cannot be used to predict graft success in patients who will undergo tympanoplasty due to chronic otitis media.

\section{Ethics}

Ethics Committee Approval: Approval was obtained from İstanbul Training and Research Hospital Ethics Committee for this study on 07.02.2020 (decision no: 2177). 
Informed Consent: Oral and written informed consent was obtained from all patients.

Peer-review: Externally peer-reviewed.

Authorship Contributions: Surgical and Medical Practices - Z.Ç., Ö.Y., A.V.S. ; Concept- Z.Ç., Ö.Y., A.V.S. ; Design - Z.C,., Ö.Y., A.V.S. ; Data Collection or Processing - Z.C.., Ö.Y., A.V.S. ; Analysis or Interpretation Z.Ç., Ö.Y., A.V.S. ; Literature Search - Z.C.., Ö.Y., A.V.S. ; Writing - Z.Ç., Ö.Y., A.V.S.

Conflict of Interest: No conflict of interest was declared by the authors.

Financial Disclosure: The authors declared that this study received no financial support.

\section{References}

1. Head K, Chong LY, Bhutta MF, Morris PS, Vijayasekaran S, Burton MJ, et al. Topical antiseptics for chronic suppurative otitis media. Cochrane Database Syst Rev 2020; 1: CD013055.

2. Dipesh S, Arun KC, Nepal A. A Comparative Study of Endoscopic versus Microscopic Cartilage Type I Tympanoplasty. Int Arch Otorhinolaryngol 2020; 24: e80-e5.

3. Sözen E, Uçal YO, Tansuker HD, Uslu CB, Korkut AY, Dadaş B. Is the tragal cartilage necessary for type 1 tympanoplasties? J Craniofac Surg 2012; 23: e280-3.

4. Kökoğlu K, Sahin MI. Use of Neutrophil, Eosinophil, Basophil, and Platelet to Lymphocyte Ratio to Predict Patient Satisfaction After Septoplasty Plus Inferior Turbinate Reduction. J Craniofac Surg 2019; 30: 1022-6.

5. Chen LC, Li SH, Lo CM, Chen YH, Huang SC, Wang YM, et al. Plateletto-lymphocyte ratio is an independent prognosticator in patients with esophageal squamous cell carcinoma receiving esophagectomy. J Thorac Dis 2019; 11: 4583-90

6. Boztepe OF, Demir M, Gün T, Bilal N, Ensari NA, Doğru H. A novel predictive marker for the viscosity of otitis media with effusion. Int J Pediatr Otorhinolaryngol 2015; 79: 2355-8.

7. Tan D, Fu Y, Tong W, Li F. Prognostic significance of lymphocyte to monocyte ratio in colorectal cancer: A meta-analysis. Int J Surg 2018; 55: 128-38.

8. Balta S, Demırer Z, Aparci M, Yildirim AO, Ozturk C. The lymphocyte-monocyte ratio in clinical practice. J Clin Pathol 2016; 69: 88-9.

9. Salviz M, Bayram 0, Bayram AA, Balikci HH, Chatzi T, Paltura C, et al. Prognostic factors in type I tympanoplasty. Auris Nasus Larynx 2015; 42: 20-3.

10. Onal K, Arslanoglu S, Songu M, Demiray U, Demirpehlivan IA. Functional results of temporalis fascia versus cartilage tympanoplasty in patients with bilateral chronic otitis media. J Laryngol Otol 2012; 126: 22-5.

11. Jalali MM, Motasaddi M, Kouhi A, Dabiri S, Soleimani R. Comparison of cartilage with temporalis fascia tympanoplasty: A meta-analysis of comparative studies. Laryngoscope 2017; 127: 2139-48.

12. Lin YC, Wang WH, Weng HH, Lin YC. Predictors of surgical and hearing long term results for inlay cartilage tympanoplasty. Arch Otolaryngol Head Neck Surg 2011; 137: 215-9.

13. Gupta S, Harshvardhan R, Samdani S. To Study the Association of the Size and Site of Tympanic Membrane Perforation with the Degree of Hearing Loss. Indian J Otolaryngol Head Neck Surg 2019; 71: 1047-52.
14. Boztepe OF, Gün T, Demir M, Gür ÖE, Ozel D, Doğru H. A novel predictive marker for the recurrence of nasal polyposis following endoscopic sinus surgery. Eur Arch Otorhinolaryngol 2016; 273: 1439-44.

15. He JR, Shen GP, Ren ZF, Qin H, Cui C, Zhang Y, et al. Pretreatment levels of peripheral neutrophils and lymphocytes as independent prognostic factors in patients with nasopharyngeal carcinoma. Head Neck 2012; 34: 1769-76.

16. Yılmaz B, Şengül E, Gül A, Alabalık U, Özkurt FE, Akdağ M, et al. Neutrophillymphocyte ratio as a prognostic factor in laryngeal carcinoma. Indian J Otolaryngol Head Neck Surg 2018; 70: 175-9.

17. Kang JW, Kim MG, Kim SS, Im HI, Dong SH, Kim SH, et al. Neutrophillymphocyte ratio as a valuable prognostic marker in idiopathic sudden sensorineural hearing loss. Acta Otolaryngol 2019; 140: 307-13

18. Li B, Zhou P, Liu Y, Wei H, Yang X, Chen T, et al. Platelet-to-lymphocyte ratio in advanced cancer: review and meta-analysis. Clin Chim Acta 2018; 483: 48-56.

19. Kurtul A, Ornek E. Platelet to lymphocyte ratio in cardiovascular diseases: a systematic review. Angiology 2019; 70: 802-18.

20. Bardash Y, Olson C, Herman W, Khaymovich J, Costantino P, Tham T. Plateletlymphocyte ratio as a predictor of prognosis in head and neck cancer: a systematic review and meta-analysis. Oncol Res Treat 2019; 42: 665-77.

21. Atan D, Özcan KM, Köseoglu S, İkincioğulları A, Çetin MA, Ensari S, et al. New predictive parameters of nasal polyposis: neutrophil to lymphocyte ratio and platelet to lymphocyte ratio. Turk J Ear Nose Throat 2015; 25: 97-101.

22. Metcalfe DD, Pawankar R, Ackerman SJ, Akin C, Clayton F, Falcone FH, et al. Biomarkers of the involvement of mast cells, basophils and eosinophils in asthma and allergic diseases. World Allergy Organ J 2016; 9: 7.

23. Motran CC, Silvane L, Chiapello LS, Theumer MG, Ambrosio LF, Volpini X, et al Helminth infections: recognition and modulation of the Immune response by Innate Immune cells. Front Immunol 2018; 9: 664.

24. Kara A, Guven M, Yilmaz MS, Demir D, Elden H. Are neutrophil, platelet and eosinophil-to-lymphocyte ratio and red blood cell distribution width can be used for nasal polyposis? Eur Arch Otorhinolaryngol 2018; 275: 409-13.

25. Çekici Y, Yılmaz M, Seçen Ö. New inflammatory indicators: association of high eosinophil-to-lymphocyte ratio and low lymphocyte-to-monocyte ratio with smoking. J Int Med Res 2019; 47: 4292-303.

26. López-Verdugo F, Furuzawa-Carballeda J, Romero-Hernández F, et al Hematological indices as indicators of silent inflammation in achalasia patients: A cross-sectional study. Medicine (Baltimore). 2020; 99: e19326.

27. Yang Z, Zhang Z, Lin F, Ren Y, Liu D, Zhong R, et al. Comparisons of neutrophilmonocyte-, eosinophil-, and basophil- lymphocyte ratios among various systemic autoimmune rheumatic diseases. APMIS 2017; 125: 863-71.

28. Balta S, Demırer Z, Aparci M, Yildirim AO, Ozturk C. The lymphocyte-monocyte ratio in clinical practice. J Clin Pathol 2016; 69: 88-9.

29. Feng X, Li L, Wu J, Zhang L, Sun Z, Li X, et al. Complete blood count score model integrating reduced lymphocyte-monocyte ratio, elevated neutrophillymphocyte ratio and elevated platelet-lymphocyte ratio predicts inferior clinical outcomes in adult t-lymphoblastic lymphoma. Oncologist 2019; 24: e1123-e31.

30. Tham T, Olson C, Khaymovich J, Herman SW, Costantino PD. The lymphocyteto-monocyte ratio as a prognostic indicator in head and neck cancer: a systematic review and meta-analysis. Eur Arch Otorhinolaryngol 2018; 275: 1663-70. 